\title{
ROOTING MINI-CUTTINGS OF Paulownia fortunei var. mikado DERIVED FROM CLONAL MINI-GARDEN ${ }^{1}$
}

\author{
Carlos André Stuepp ${ }^{2}$, Katia Christina Zuffellato-Ribas ${ }^{3}$, Henrique Soares Koehler ${ }^{4}$ e Ivar Wendling ${ }^{5}$
}

\begin{abstract}
We aimed to evaluate the technical efficiency of mini-cuttings technique on vegetative propagation of Paulownia fortunei (Seem.) Hemsl. var. Mikado, as well as the possible existence of anatomical barriers to its rooting. Therefore, plants originated from cuttings formed the mini-stumps and, consequently the clonal mini-garden, which was conducted in semi-hydroponic system. We evaluated the survival of mini-stumps and sprouts production for five successive collects, the percentage of mini-cuttings rooting and their anatomical description. The mini-cuttings were prepared with about 6 to $8 \mathrm{~cm}$ in length and two leaves reduced by about $50 \%$ in the upper third, being remained an area of, approximately $78 \mathrm{~cm}^{2}(10 \mathrm{~cm}$ diameter $)$. The mini-cuttings were placed in tubes of $53 \mathrm{~cm}^{3}$, with substrate formed with fine vermiculite and carbonized rice hulls $(1: 1$ $\mathrm{v} / \mathrm{v}$ ) and rooted in acclimatized greenhouse. After 30 days we evaluated the percentage of rooted mini-cuttings, radicial vigor (number and length of roots / mini-cutting), callus formation, emission of new shoots and maintenance of the original leaves. The mini-stumps showed $100 \%$ survival after five collects and an average production of 76-114 mini-cuttings $/ \mathrm{m}^{2} /$ month and rooting ranged from 70 to $90 \%$. Mini-cuttings technique is efficient in to propagate adult propagules of the species and there are not anatomical barriers preventing roots emission.
\end{abstract}

Keywords: Rejuvenation; Mini-stumps; Anatomy.

\section{ENRAIZAMENTO DE MINIESTACAS DE Paulownia fortunei var. mikado PROVENIENTES DE MINIJARDIM}

\begin{abstract}
RESUMO - Este estudo objetivou avaliar a eficiência técnica da miniestaquia na propagação vegetativa de Paulownia fortunei (Seem.) Hemsl. var. mikado, bem como a possível existência de barreiras anatômicas ao enraizamento de miniestacas. Para tanto, a partir de mudas originárias de estaquia formaram-se minicepas, as quais foram conduzidas em sistema semi-hidropônico. Avaliaram-se a sobrevivência das minicepas e a produção de miniestacas durante cinco coletas sucessivas, a porcentagem de enraizamento das miniestacas e sua descrição anatômica. As miniestacas foram preparadas com cerca de 6 a $8 \mathrm{~cm}$ de comprimento e duas folhas reduzidas em torno de 50\%, no terço superior, ficando uma superfície aproximada de $78 \mathrm{~cm}^{2}$ (10 cm de diâmetro). As miniestacas foram inseridas em tubetes de $53 \mathrm{~cm}^{3}$, com substrato à base de vermiculita fina e casca de arroz carbonizada (1:1 em v/v), e acondicionadas em casa de vegetação climatizada. Após 30 dias foram avaliados a porcentagem de miniestacas enraizadas, o vigor radicial (número e comprimento de raízes/miniestaca), a formação de calos, a emissão de novos brotos e a manutenção das folhas originais. As minicepas apresentaram 100\% de sobrevivência após cinco coletas e uma produção média de 76 a 114 miniestacas $/ \mathrm{m}^{2} / \mathrm{mês}$, e o enraizamento variou de 70 a $90 \%$. Conclui-se que a técnica da miniestaquia é eficiente na propagação vegetativa de propágulos adultos da espécie e não ocorrem barreiras anatômicas impedindo a emissão do sistema radicial.
\end{abstract}

Palavras-chave: Rejuvenescimento; Minicepas; Anatomia.

\footnotetext{
${ }^{1}$ Recebido em 25.03.2013 aceito para publicação em 24.03.2015

${ }^{2}$ Universidade Federal do Paraná (UFPR), Programa de Pós-Graduação em Agronomia, Curitiba, Paraná, Brasil. E-mail: <carlos.stuepp@ufpr.br>.

${ }^{3}$ Universidade Federal do Paraná (UFPR), Departamento de Botânica, Curitiba, Paraná, Brasil. E-mail: <kazu@ufpr.br>. ${ }^{4}$ Universidade Federal do Paraná (UFPR), Departamento de Fitotecnia e Fitossanitarismo, Curitiba, Paraná, Brasil. E-mail: <koehler@ufpr.br>.

${ }^{5}$ Empresa Brasileira de Pesquisa Agropecuária, Centro Nacional de Pesquisa de Florestas, Colombo, Paraná, Brasil. E-mail: <ivar.wendling@embrapa.br>.
} 


\section{INTRODUCTION}

Vegetative propagation or cloning consist of multiplying asexually plant parts (cells, tissues, organs) to generate new plants genetically identical to the mother tree, not occurring gene recombination (HARTMANN et al., 2011). In this context, mini-cuttings technique can be classified as an evolution of the cutting process, since it tends to reduce the area required for mother plants conduction by adopting clonal minigarden, reducing also the rooting and acclimatization period and, above all, making unnecessary in some cases the application of plant growth regulators to induce rooting (XAVIER et al., 2003;WENDLING et al., 2005; FERRIANI et al., 2010).

The Paulownia genus belongs to the Scrophulariaceae family and is originally from East Asia, being popularly known as quiri. From the 15 species of this genus, the most popular and cultivated are Paulownia elongata, $P$. fargesii, $P$. fortunei, $P$. glabrata, taiwaniana $P$. and $P$. tomentosa (BONNER; BURTON, 1974; ZHU et al, 1986). The a genus has good resistance to low temperatures, being well adapted to southern Brazil, mainly in the state of Paraná, where it was introduced in the 1970 (LORENZI et al., 2003).

The slowness in the germination process, combined with large phenotypic variation of sexual propagated trees, generates the need for more detailed studies with regarding alternatives to propagate the species (BERGMANN, 1997). In this sense, we can demonstrate the potential of mini-cutting technique for obtaining a large amount of seedlings in a short time.

To obtain success in the process of propagation by mini-cuttings technique, it is necessary knowledge about the existence of limiting anatomical barriers to rooting process is required (BITENCOURT et al., 2009). Commonly found in tree species, an example of anatomical barrier to emit roots are the rings of continuous sclerenchyma between the phloem and cortex, resulting in an outer layer to the origin of the roots (HARTMANN et al., 2011) .

Based on the above, this study aimed to evaluate the technical efficiency of mini-cuttings technique for vegetative propagation of Paulownia fortunei var. mikado, as well as the possible existence of anatomical barriers to rooting mini-cuttings.

\section{MATERIAL AND METHODS}

\subsection{Mini-cuttings technique}

Rooted cuttings of Paulownia fortunei var. mikado were transferred to semi-hydroponic system suspended in sand bed, spaced $20 \mathrm{~cm} \times 20 \mathrm{~cm}$, in February 2012, at the Forest Species Propagation Laboratory (Embrapa Forests, Colombo-PR). To obtain the rooted cuttings were used 10 adult mother plants of approximately 20years-old and with $60-80 \mathrm{~cm}$ diameter at breast height (dbh) located in the city of Aurora - SC $\left(27^{\circ} 23^{\prime} 28.57^{\prime \prime} \mathrm{S}\right.$ e 49 $\left.38^{\prime} 43.30^{\prime \prime} \mathrm{W}\right)$, with an approximate altitude of $700 \mathrm{~m}$.

After 30 days needed for plants adaptation to the semi-hydroponic system, apical sprout were pruned for mini-stumps homogenization. The pruning was performed $10 \mathrm{~cm}$ above the colon region of ministumps, taking care to keep at least two remaining leaves (Figure 1a).

The clonal mini-garden was stablished in a greenhouse covered with polyethylene where the ministumps received drip fertigation three times daily at an average flow rate of $6 \mathrm{~L} \mathrm{~m}^{-2}$ day $^{-1}$. The nutrient solution was adapted from Wendling et al. (2007), comprising monoammonium phosphate $\left(0.065 \mathrm{~g} \mathrm{~L}^{-1}\right)$, magnesium sulfate $\left(0.40 \mathrm{~g} \mathrm{~L}^{-1}\right)$, potassium nitrate $\left(0.44 \mathrm{~g} \mathrm{~L}^{-1}\right)$, ammonium sulphate $\left(0.2 \mathrm{~g} \mathrm{~L}^{-1}\right)$, potassium sulphate (0.07 $\left.\mathrm{g} \mathrm{L}^{-1}\right)$, calcium chloride $\left(0.40 \mathrm{~g} \mathrm{~L}^{-1}\right)$, boric acid (2.88 $\left.\mathrm{mg} \mathrm{L}^{-1}\right)$, manganese sulfate $\left(3.70 \mathrm{mg} \mathrm{L}^{-1}\right)$, sodium molybdate $\left(0.18 \mathrm{mg} \mathrm{L}^{-1}\right)$, zinc sulfate $\left(0.74 \mathrm{mg} \mathrm{L}^{-1}\right)$ and hydro-iron powder $\left(81.80 \mathrm{mg} \mathrm{L}^{-1}\right)$. The solutions was replaced every two weeks, the $\mathrm{pH}$ being adjusted to 6.2 at $25{ }^{\circ} \mathrm{C}$ with hydrochloric acid $(\mathrm{HCl})$ or sodium hydroxide $(\mathrm{NaOH})$, both $1 \mathrm{M}$.

The mini-cuttings collections were made selectively at variable intervals of 15-20 days, when sprouts bigger than $5 \mathrm{~cm}$ in length and with at least three pairs of leaves were collected. Thus, mini-stumps were subjected to five successive collections, which corresponded to the used treatments. Over the collections we evaluated the percentage of mini-stumps survival (SM) and the production of mini-cuttings per square meter (PMQ).

The experiment was conducted in a completely randomized design, being the mini-garden based on 40 mini-stumps and the assessment carried out in the following periods: 02/04/2012; 20/04/2012; 08/05/2012; 23/05/2012 and 12/06/2012. The mini-cuttings had an

Revista Árvore, Viçosa-MG, v.39, n.3, p.497-504, 2015 

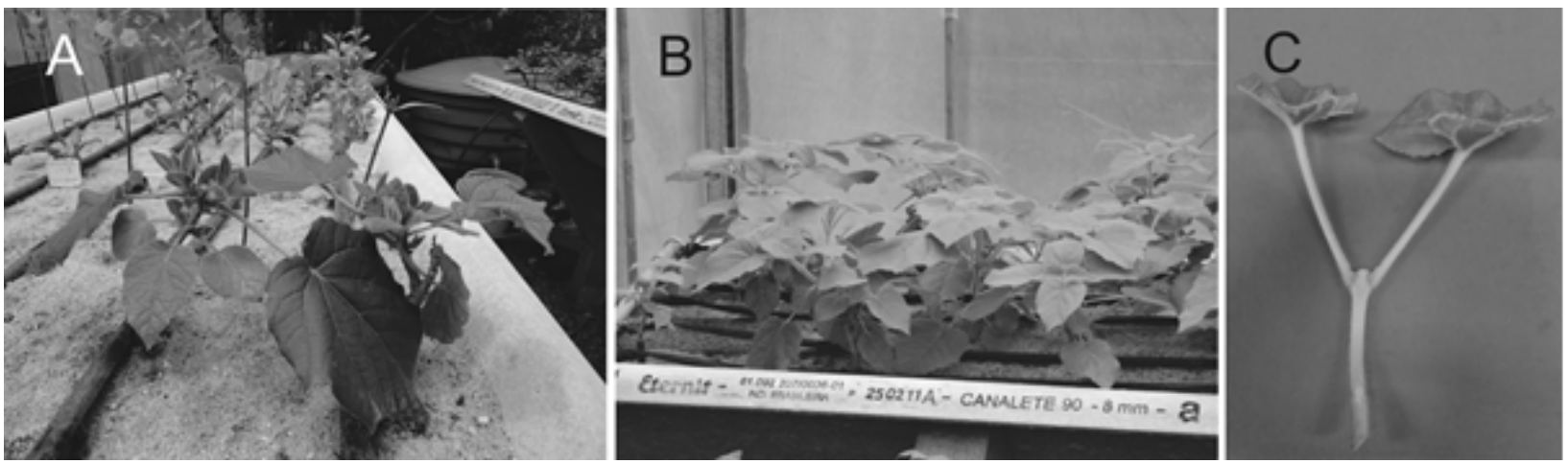

Figure 1 - Ministumps of Paulownia fortune var. mikado: A) One week after apical pruning for conduction; B) 30 days after pruning; and C) General aspect of semi-hardwood minicutting.

Figura 1 - Minicepas de Paulownia fortunei var. mikado: A) Uma semana após a poda apical para condução; B) 30 dias após a poda apical; e C) Aspecto geral da miniestaca semilenhosa.

average diameter of about $0.6 \mathrm{~cm}$ and were prepared with 6 to $8 \mathrm{~cm}$ in length with a bevel cut at the base and straight cut in the upper portion, remaining two leaves at the apex with around $50 \%$ of area reduction, remaining approximately $78.5 \mathrm{~cm}^{2}(10 \mathrm{~cm}$ diameter) (Figure 1c). During the process of preparation, the mini-cuttings were kept in water to avoid dehydration.

The mini-cuttings were inserted about $2 \mathrm{~cm}$ deep in polypropylene tubes with $55 \mathrm{~cm}^{3}$ capacity, with substrate based on fine vermiculite and carbonized rice hulls (1:1 v/v) (WENDLING; XAVIER, 2005). After preparation, they were placed in acclimatized greenhouse with intermittent misting system $\left(24 \pm 2^{\circ} \mathrm{C}\right.$ air temperature and more than $80 \%$ relative humidity).

Thirty days after installation of the experiment the following variables were evaluated: rooting percentage (live mini-cuttings who had roots of at least $2 \mathrm{~mm}$ in length); number of roots per mini-cuttings; length of the three major roots per mini-cuttings $(\mathrm{cm})$; percentage of mini-cuttings with callus (live mini-cuttings without roots, with undifferentiated cell mass formation at the base); survival percentage (live mini-cuttings who did not have radicial induction or callus formation); percentage of mortality (mini-cuttings with necrotic tissue); percentage of sprouted mini-cuttings (minicuttings that formed new leaves, with or without root and callus formation); leaves maintenance in mini-cuttings (percentage of mini-cuttings with retention of original leaves).

The experiments were conducted in a completely randomized design with five successive collections and four replications of 20 mini-cuttings each. The variances of the treatments were evaluated for homogeneity by Bartlett test and those with significant differences by the $\mathrm{F}$ test had their means compared by Tukey test at $5 \%$ error probability (BITENCOURT et al., 2009).

\subsection{Anatomical analysis}

During the first collection of mini-cuttings samples of approximately $2 \mathrm{~cm}$ from its base were collected, fixed in FAA70 for 24 hours (JOHANSEN, 1940; RICKLI, 2012), and preserved in $70 \%$ alcohol until the beginning of blocks preparation and anatomical analyzes, carried out in Plant Anatomy Laboratory - Department of Botany, UFPR, Curitiba - PR. The samples were cut into fragments of $1.0 \mathrm{~cm}$ and included in blocks with PEG (polyethylene glycol 1500), set in wooden tutors and kept in the refrigerator for 24 hours. Subsequently, the blocks were sectioned in rotation microtome (Olympus CUT 4055) and laminated with $15 \mu \mathrm{m}$ (KRAUS; ARDUIN, 1997). While being made, the tape shaped cuts were submerged in Petri dishes with distilled water for PEG dissolution. Finally, the sections were submitted to histochemical tests with Lugol for starch grains identification; ferric chloride for phenolic compounds identification and SUDAM III for lipids identification. Some sections were also subjected to double staining with safrablau ( $5 \mathrm{ml}$ aqueous solution of $1 \%$ safranin - $95 \mathrm{ml}$ of aqueous $1 \%$ Astra Blue solution) for cellulose and lignin identification (KRAUS; ARDUIN, 1997).

After these procedures, semi-permanent slides were made using gelatin-glycerin, and subsequent sealing

Revista Árvore, Viçosa-MG, v.39, n.3, p.497-504, 2015 
with colorless nail polish. The slides were analyzed and documented at Phycology Laboratory - Department of Botany, UFPR, Curitiba - PR, Brazil, by photomicrographs in light microscope Zeiss with digital Sony Cyber-shot P72 camera coupled.

\section{RESULTS}

The survival of mini-stumps after five successive collects was $100 \%$ (data not shown), while the production of mini-cuttings ranged from 81 (collect 5) to 147 (collect 1) per collect and 76 (collect 5) to 114 (collect 2) per square meter per month (Table 1).

Regarding rooting of mini-cuttings, we only observed significant variations between collections 3 and 5 with 70 and $90 \%$, respectively. For average number of roots and average length of the three major roots/mini-cutting, on the other hand, no significant differences were observed. The number of roots ranged from 3.0 (collect 2) to 4.6 (collect 5) and the average length of three major roots $/$ mini-cutting from $3.8 \mathrm{~cm}$ (collect 5) to $5.4 \mathrm{~cm}$ (collect 2) (Table 2).

For the other variables, i.e., percentage of minicuttings with callus, mini-cuttings survival and percentage of mini-cuttings with maintained and sprouted leaves, there were no significant differences between the different mini-cuttings collects (Table 3).

\section{DISCUSSION}

The excellent adaptation of mini-stumps to the used semi-hydroponic system, verified by the nonoccurrence of mortality, vigorous vegetative growth, without the manifestation of leaf burning throughout the experiment demonstrated the efficiency of nutrient solution for mini-stumps management purposes of the species. On the other hand, the adoption of a minicuttings management and collection methodology which aimed to preserve mini-stumps over successive collects also proved to be fundamental and is in accordance with different studies for different Eucalyptus species (MORI DA CUNHA et al., 2005; CUNHA et al., 2005). According to Ferriani et al. (2010), the excessive removal of sprouts in mini-stumps growing in a mini-garden system can induce its higher mortality, mainly due to phytotoxic effects of high nutrients concentrations.

The mini-stumps showed the same mini-cuttings production capacity, except in the first collect, where the higher production can mainly be explained by the longer interval period until following collections (30 days). These results have been verified in most studied species, such as Eucalyptus spp. where Wendling et al. (2000) found a superior production in the first collect compared to others. In Psidium guajava L. 'paluma' mini-cuttings technique the first collect was realized 39 days after the first pruning, getting an average of 1.5 sprouts per mini-stump (MARINHO et al., 2009). In studies with Toona ciliata mini-cuttings technique, first collection was performed only 70 days after first pruning, with production of 1.1 sprouts per mini-stump (SOUZA et al., 2009).

A good sprouts production in a clonal mini-garden is essential to succeed in mini-cuttings propagation, being a key factor for the viability of the technique. Besides other factors, the production can vary depending on the characteristics of each species. For Paulownia fortune var. mikado we found that sprouts in mini-garden showed larger leaves than other species traditionally propagated by mini-cuttings technique, which could reduce the amount of sprouts per mini-stump due to the higher occupied area in clonal mini-garden (Figure 1b). For different cultivars of guava (Psidium guajava L.), an average production ranging from 0.7 to 5.0 mini-cuttings per mini-stump at different collection intervals was found (ALTOÉ, 2011). However, for different species and clones of Eucalyptus sp., this variation in mini-cuttings production tends to be greater, between 1.7 and 11.9 (TITON et al., 2003).

The mini-cuttings production potential per square meter of Paulownia fortunei var. mikado showed a declining trend over the five successive collects, with 92 mini-cuttings $/ \mathrm{m}^{2}$ in the first collect and 50 mini-cuttings $/ \mathrm{m}^{2}$ in the last collect, averaging $65 \mathrm{mini}$ cuttings $/ \mathrm{m}^{2}$ (Table 1 ). The decrease in mini-cuttings production over the five successive collects reflects the trend seen previously for the number of minicuttings per mini-stump, due to decreases in temperatures throughout fall.

The 30-day maintenance of mini-cuttings in greenhouse for rooting was satisfactory, given the good rooting results obtained. This period coincides with the maintenance period in rooting beds of other forest species such as Erythrina falcata (WENDLING et al., 2005) and Eucalyptus grandis (WENDLING; XAVIER, 2003).

Revista Árvore, Viçosa-MG, v.39, n.3, p.497-504, 2015 
Table 1 - Interval between collections and production of minicuttings per collection, per $\mathrm{m}^{2} /$ collection and per $\mathrm{m}^{2} / \mathrm{month}$ of Paulownia fortune var. mikado.

Tabela 1 - Intervalo entre as coletas e produção de miniestacas/coleta, por $\mathrm{m}^{2} /$ coleta e por $\mathrm{m}^{2} / \mathrm{mês}$ de Paulownia fortunei var. mikado.

\begin{tabular}{|c|c|c|c|c|}
\hline [COLECTS] & Collects intervals (days) & Mini-cuttings/ collect & Mini-cuttings $/ \mathrm{m}^{2} /$ collect & Mini-cuttings $/ \mathrm{m}^{2} /$ month \\
\hline 1 & & 147 & 92 & 92 \\
\hline 2 & 18 & 109 & 68 & 114 \\
\hline 3 & 18 & 97 & 60 & 101 \\
\hline 4 & 15 & 90 & 56 & 112 \\
\hline 5 & 20 & 81 & 50 & 76 \\
\hline Means & 18 & 105 & 65 & 99 \\
\hline
\end{tabular}

Table 2 - Percentage of rooting, root number and average length of the three longest roots/minicuttings of Paulownia fortune var. mikado, from five successive collections between April and June/2012.

Tabela 2 - Porcentagem de enraizamento, número de raízes e comprimento médio das três maiores raízes/miniestaca de Paulownia fortunei var. mikado, provenientes de cinco coletas sucessivas, entre abril e junho/2012.

\begin{tabular}{cccc}
\hline [COLECTS] & $\begin{array}{c}\text { ROOTING } \\
(\%)\end{array}$ & $\begin{array}{c}\text { Roots number/ } \\
\text { mini-cutting }\end{array}$ & $\begin{array}{c}\text { Three Longest Roots/ } \\
\text { Mini-Cutting Length (cm) }\end{array}$ \\
\hline 1 & $76,2 \mathrm{ab}$ & 3,55 & 4,69 \\
2 & $80,0 \mathrm{ab}$ & 2,97 & 5,38 \\
4 & $70,0 \mathrm{~b}$ & 4,02 & 5,38 \\
5 & $73,7 \mathrm{ab}$ & 3,85 & 3,84 \\
Means & $90,0 \mathrm{a}$ & 4,57 & 4,66 \\
Variation coeficient $(\%)$ & 78,00 & 3,79 & 18,94 \\
\hline
\end{tabular}

Means followed by the same letter in the column do not differ by Tukey test at $5 \%$ probability.

Médias seguidas pela mesma letra na coluna não diferem entre si pelo teste de Tukey a 5\% de probabilidade.

Tabela 3 - Porcentagem de calos (C), sobrevivência (S), mortalidade (M), brotação (B) e de manutenção de folhas (MF) em miniestacas de Paulownia fortunei var. mikado, provenientes de cinco coletas sucessivas, entre abril e junho/ 2012.

Table 3 - Percentage of callus (C), survival (S), mortality (M), sprouts (B) and leaves maintenance (MF) on minicuttings of Paulownia fortune var. mikado, from five successive collections between april and june/2012.

\begin{tabular}{|c|c|c|c|c|c|}
\hline [COLLECTS] & $\mathrm{C}(\%)$ & $\mathrm{S}(\%)$ & $\mathrm{M}(\%)$ & B $(\%)$ & MF $(\%)$ \\
\hline 1 & 16,25 & 7,50 & 16,25 & 6,25 & 75,00 \\
\hline 2 & 13,75 & 10,00 & 10,00 & 8,75 & 66,25 \\
\hline 3 & 21,25 & 11,25 & 18,75 & 3,75 & 66,25 \\
\hline 4 & 20,00 & 11,25 & 15,00 & 2,50 & 71,25 \\
\hline 5 & 11,25 & 2,50 & 7,50 & 6,25 & 73,75 \\
\hline Means & 16,50 & 8,50 & 13,50 & 5,50 & 70,50 \\
\hline Variation coeficient $(\%)$ & 50,10 & 79,65 & 60,82 & 74,23 & 12,55 \\
\hline
\end{tabular}

The results for number of roots/mini-cutting can be considered satisfactory, taking into account the 30 days of evaluation. These results are promising and are essential for recommendation of mini-cutting technique for the species, since a good radicial system contributes significantly to increased efficiency in the absorption of nutrients, and especially the development of plants in field (REIS et al., 2000).

The low rates of callus emission associated with high rooting rates demonstrate the juvenility of this material. This fact is of interest when the aim is getting

Revista Árvore, Viçosa-MG, v.39, n.3, p.497-504, 2015 
high quality plants with a good roots system development in a suitable period. According to Hartmann et al. (2011), low callus formation rates in cuttings can be considered indicative of propagule juvenility, a fact verified for mini-cuttings of Paulownia fortune var. mikado. The lowest callus formation rate in Paulownia fortune var. mikado mini-cuttings occurred in the fifth collect, where the best rooting results were obtained, demonstrating the fact that this tissue differentiation from the base of the mini-cuttings to callus formation not necessarily result in de-differentiation to form adventitious roots, which are generated directly (HARTMANN et al., 2011).

The low sprouts rates formation on Paulownia fortune var. mikado mini-cuttings are due to evaluation at 30 days after installation, connoting possibly insufficient time to occur issuing shoots. On the other hand, these results may be linked to high leaf maintenance on mini-cuttings, and consequently no emission of new shoots. This fact was verified for Olea europaea cuttings where the absence of leaves, or even their fall during rooting process, resulted in stimulating the emission of new shoots from axillary buds located at base of leaves, once dormant (PIO et al., 2005).

The leaves maintenance rates found for mini-cuttings of Paulownia fortune var. mikado are possibly linked to the fact that their maintenance is related to the start of root formation process, where all the metabolites synthesized even in the mother plant can be transported to the rooting region after mini-cuttings preparation, besides the regulatory function of their water status (OLIVEIRA et al., 2001). Mayer and Pereira (2003) proved the influence of leaf retention in Prunus mume cuttings on rooting speed, noting that the absence of leaves committed rooting and resulted in higher rates of callus formation or cuttings dead. In a similar study, using softwood cuttings of Prunus persica cv. Jubilee, with or without indole butyric acid treatment, leaves maintenance was a major factor for rooting success (MINDELLO NETO; BALBINOT JUNIOR, 2004).

\subsection{Anatomical analysis}

On the base of semi-hardwood mini-cuttings (Figure 2) is characterized by low lignification in their tissues. The stem shows secondary growth, with periderm at the beginning of formation, in sub epidermal position. Cortex is quite thick, composed externally by 8-10 layers of collenchyma and internally with 12 to 14 layers of parenchyma. Also

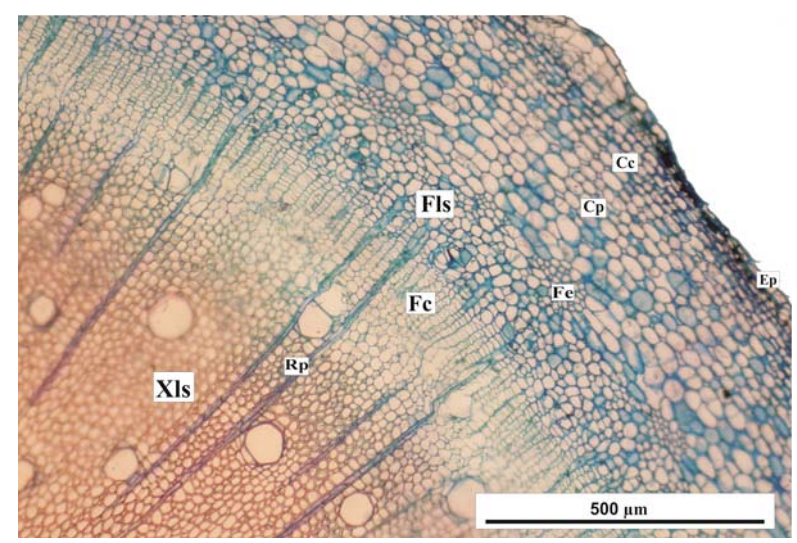

Figure 2 - Cross section of Paulownia fortunei var. mikado minicutting: epidermis (Ep), collenchyma (Cc) and parenchymal cells ( $\mathrm{Cp})$, not scarified fiber bundles (Fe), secondary phloem (Fls), band exchange $(\mathrm{Fc})$, parenchyma rays $(\mathrm{Rp})$ and secondary xylem (X1s).

Figura 2 - Secção transversal de miniestaca caulinar de Paulownia fortunei var. mikado: epiderme (Ep), células colenquimáticas (Cc), células parenquimáticas ( $C p)$, feixes de fibras não esclerificados (Fe), floema secundário (Fls), faixa cambial $(F C)$, raios parenquimáticos $(R p)$ e xilema secundário (Xls).

in the cortical region are found not sclerified fiber bundles arranged in a discontinuous annulus (Figure 2).

Secondary phloem is continuous, composed of sieve tube elements, companion cells and axial and radial parenchyma. The cambium range is formed by several layers of undifferentiated cells being visible intense cellular activity, represented by a greater number of cells layers in this organ (Figure 2). In secondary xylem can be verified the existence of parenchyma rays, with 2, 3 or 4 rows of cells, and the presence of vessels mostly singly or in radial clusters, fibers and paratracheal parenchyma (Figure 2).

Medulla is composed of parenchyma, which undergoes lysis over time, forming a fistula or gap. Starch grains, phenolic compounds and lipids were not observed in the analyzed material.

\section{CONCLUSIONS}

Propagation of Paulownia fortunei var. mikado by mini-cuttings technique is feasible, with high ministumps survival and rooting mini-cuttings rates and there were no anatomical barriers to rooting.

Revista Árvore, Viçosa-MG, v.39, n.3, p.497-504, 2015 


\section{ACKNOWLEDGEMENTS}

To Embrapa Forestry and the entire team of Forest Species Propagation Laboratory. To teams of Anatomy and Plant Phycology Laboratories, UFPR.

To the Program of Restructuring and Expansion of Federal Universities - REUNI and to Higher Education Personnel Improvement Coordination - CAPES, for granting master's scholarship to the first author.

\section{REFERENCES}

ALTOÉ, J.A.; MARINHO, C.S.; TERRA, M.I.C.; CARVALHO, A.J.C. Multiplicação de cultivares de goiabeira por miniestaquia. Bragantia, v.70, n.4, p.801-809, 2011.

BERGMANN, B.A.; MOON, H.K. In vitro adventitious shoot production in Paulownia. Plant Cell Reports, v.16, p.315-319, 1997.

BITENCOURT, J.; ZUFFELLATO-RIBAS, K.C.; WENDLING, I.; KOEHLER, H.S. Enraizamento de estacas de erva-mate (Ilex paraguariensis A. St.Hill.) provenientes de brotações rejuvenescidas.

Revista Brasileira de Plantas

Medicinais, v.11, n.3, p.277-281, 2009.

BONNER, F.T.; BURTON, J.D. Paulownia tomentosa (Thunb.) Sieb. \& Suec,. Royal paulownia. In: SCHOPMEYER, C.S. (Coord). Seeds of woody plants in the United States. Washington: USDA-Forest Service, 1974. p.572-573.

CUNHA, A.C.M.C.M.; WENDLING, I.; SOUZA JÚNIOR, L. Produtividade e sobrevivência de minicepas de Eucalyptus benthamii Maiden et Cambage em sistema de hidroponia e em tubete, Ciência Florestal, v.15, n.3, p.307-310, 2005.

FERRIANI, A.P.; ZUFFELLATO-RIBAS, K.C.; WENDLING, I. Miniestaquia aplicada a espécies florestais. Revista Agro@mbiente on line, v.4, n.2, p.102-109, 2010.

HARTMANN, H.T.; KERSTER, D.E.; DAVIES JR, F.T.; GENEVE, R.L. Hartmann and Kerster's plant propagation: principles and practices. 8.ed. Boston: Prentice Hall, 2011. 915p.

JOHANSEN, D.A. Plant microtechnique. New York: McGraw-Hill, 1940. 523p.

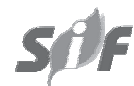

KRAUS, J.; ARDUIN, M. Manual básico de métodos em morfologia vegetal. Seropédica: EDUR, 1997. 198p.

LORENZI, H., Árvores Exóticas no Brasil - Madeireiras, ornamentais e aromáticas. Nova Odessa: Instituto Plantarum, 2003. 368p.

MARINHO, C.S.; MILHEM, L.M.A.; ALTOÉ, J.A.; BARROSO, D.G.; POMMER, C.V. Propagação da goiabeira por miniestaquia. Revista Brasileira de Fruticultura, v.31, p.607-611, 2009.

MAYER, N.A.; PEREIRA, F.M. Enraizamento de estacas herbáceas de quatro clones de umezeiro (Prunus mume Sieb. et Zucc.) durante o inverno ameno, em Jaboticabal-SP. Revista

Brasileira de Fruticultura, v.25, n.3, p.505-507, 2003.

MINDÊLLO NETO, U.R.; BALBINOT JÚNIOR, A.A. Enraizamento de estacas herbáceas de pessegueiro, cultivar Jubileu, com imersão rápida em AIB. Revista Agropecuária

Catarinense, v. 17, n.3, p.88-90, 2004.

MORI DA CUNHA, A.C.M.C.; WENDLING, I.; SOUZA JÚNIOR, L. Produtividade e sobrevivência de minicepas de Eucalyptus benthamii Maiden et Cambage em sistema de hidroponia e em tubetes. Ciência Florestal, v.15, n.3, p.307-310, 2005.

OLIVEIRA, M.C.; RIBEIRO, J.F.; RIOS, M.N.S.; REZENDE, M.E. Enraizamento de estacas para produção de mudas de espécies nativas de matas de galeria. Brasília: Embrapa, 2001. 4p. (Recomendação Técnica, 41)

PIO, R.; BASTOS, D.C.; BERTI, A.J.; SCARPARE FILHO, J.A.; ENTELMANN, F.A.; ALVES, A.S.R.; BETTIOL NETO, J.E. Enraizamento de diferentes tipos de estacas de oliveira (Olea europaea L.) utilizando ácido indol butírico. Ciência Agrotecnológica, v.29, n.3, p.562-567, 2005.

REIS, J.M.R.; CHALFUN, N.N.J.; LIMA, L.C.O.; LIMA, L.C. Efeito do estiolamento e do ácido indol butírico no enraizamento de estacas do porta-enxerto Pyrus calleryana Dcne. Ciência Agrotécnologia, v.24, n.4, p.931-938, 2000.

Revista Árvore, Viçosa-MG, v.39, n.3, p.497-504, 2015 
RICKLI, H.C. Propagação de guaricica (Vochysia bifalcata Warm.) por sementes e estaquia caulinar. 2012. 105f. Dissertação (Mestrado em Agronomia - Produção Vegetal) Universidade Federal do Paraná, Curitiba, 2012.

SILVA, F.A.S. ASSISTAT versão 7.6 beta. Campina Grande: Assistência Estatística, Departamento de Engenharia Agrícola do CTRN Universidade Federal de Campina Grande, Campus de Campina. Disponível em: $<\underline{\text { http: } / /}$ www.assistat.com $>$. Acesso em: 18 dez. 2011.

SOUZA, J.C.A.V.; BARROSO, D.G.; CARNEIRO, J.G.A.; TEIXEIRA, S.L.; BALBINOT, E.

Propagação vegetativa de cedro-australiano (Toona ciliata M. Roemer) por miniestaquia. Revista Árvore, v.33, n.2, p.205-213, 2009.

TITON, M.; XAVIER, A.; REIS, G.G.; OTONI, W.C. Eficiência das minicepas e microcepas na produção de propágulos de clones de Eucalyptus grandis, Revista Árvore, v.27, n.5, p.619-625, 2003.

WENDLING, I.; XAVIER, A.; GOMES, J.M.; PIRES, I.E.; ANDRADE, H.B. Efeito do regulador de crescimento AIB na propagação de clones de Eucalyptus spp. por miniestaquia. Revista Árvore, v.24, n.2, p.187-192, 2000.

WENDLING, I.; XAVIER, A. Miniestaquia seriada no rejuvenescimento de clones de Eucalyptus.
Pesquisa Agropecuária Brasileira, v. 38 , p.475-480, 2003.

WENDLING, I.; FERRARI, M.P.; DUTRA, L.F. Produção de mudas de corticeira-domato (Erythrina falcata Bentham) por miniestaquia a partir de propágulos juvenis. Colombo: 2005. (Comunicado Técnico Embrapa Florestas, 130)

WENDLING, I.; XAVIER, A. Influência do ácido indolbutírico e da miniestaquia seriada no enraizamento e vigor de miniestacas de clones de Eucalyptus grandis, Revista Árvore, v.29, n.6, p.921-930, 2005.

WENDLING, I.; DUTRA, L.F.; GROSSI, F. Produção e sobrevivência de miniestacas e minicepas de erva-mate cultivadas em sistema semi-hidropônico. Pesquisa Agropecuária Brasileira, v.42, p.289-292, 2007

XAVIER, A.; SANTOS, G.A.; OLIVEIRA, M.L. Enraizamento de miniestaca caulinar e foliar na propagação vegetativa de cedro-rosa (Cedrela fissilis Vell.). Revista Árvore, v.27, n.3, p.351-356, 2003.

ZHU, Z.H.; LU, X.Y.; XIONG, Y.G. Paulownia in china: Cultivation and utilization. Singapore: Asia Network for Biological Science; International Development Research Centre, 1986. Disponível em: <http://www.idrc.ca/library/document/ 071235/071235c.htm> Acesso em: 17 de mar. 2012. 